\title{
分極反転を用いた電気光学デバイスによるレーザー光制御
}

\author{
森本 朗裕，和田 泰輔 \\ 立命館大学 理工学部電子光情報工学科 (广5525-8577 滋賀県草津市野路東1-1-1)
}

\section{Laser Beam Control by Electro-Optic Devices Using Polarization Reversal}

\author{
Akihiro MORIMOTO and Taisuke WADA \\ Department of Photonics, College of Science and Engineering, Ritsumeikan University, \\ 1-1-1, Noji-higashi, Kusatsu, Shiga 525-8577
}

(Received December 11, 2003)

\begin{abstract}
Polarization reversal of an electro-optic crystal makes spatial control of the modulation polarity in the crystal. Electro-optic modulators using polarization reversal have remarkable features of spatial modulation suitable especially for microwave modulation. This paper reviews electro-optic devices with polarization reversal. An electro-optic modulator with periodic polarization reversal is an efficient phase modulator in microwave frequency regions with quasi-velocity-matching, which is useful not only in modulators but also spectral comb generators and coherence controllers. An electro-optic deflector with slant polarization reversal in a beam diameter is a typical application. Novel electro-optic devices are possible with this technique.
\end{abstract}

Key Words: Polarizaion reversal, Domain inversion, Electro-optic devices, Laser beam conrtol, Ultrafast

1.はじめに

光の周波数は数百 $\mathrm{THz}$ から $\mathrm{PHz}$ の領域にあり，きわめて 広帯域である。また，それと同時に，光波の波長はサブ マイクロメートルからナノメートルの領域にあり，短波 長性に起因する空間並列性がある。このような光波の持 つ広帯域性，高速性と空間並列性を相互に有効に利用す ることが, 光制御に扔いて重要な課題である1).

強誘電結晶の分極反転は, 非線形光学素子としての応 用だけでなく，こうした光制御用電気光学デバイス分野 での利用も期待できる. 多くの電気光学結晶は強誘電結 晶であり，分極反転によれば電気光学係数の符号を一つ の素子内で自在に制御することができ，結晶を通過する 光波に対してさまざまな光制御が実現できるのである. 特に，空間的に変調の符号が制御できることから，空間 光制御素子の新しい作成法として注目されている2). 電気 光学素子は動作波長領域が半導体素子と比べてきわめて 広く, また超高速動作が可能であるため, 広帯域な光周 波数分離・制御素子や，さまざまな極限光制御デバイス への利用が期待されている.

以上のような観点から，分極反転を用いた超高速光制 御のための光変調器, 光空間変調器の開発が近年精力的 に進められているが，ここではその概要について報告す る.

\section{2. 分極反転光空間变調器}

よく知られているように, 強誘電結晶は強い電界を印 加するなどによってその結晶軸の向きが反転する。これ が分極反転である. $\mathrm{LiNbO}_{3}$ や $\mathrm{LiTaO}_{3}$ などの電気光学結晶 も強誘電結晶であり, 強い電界印加によって結晶軸の向 きが反転する，ただし，この電界は通常の $\mathrm{LiTaO}_{3} て ゙ は 22$ $\mathrm{kV} / \mathrm{mm}$ にも㧍よび, 結晶の放電破壊電界に近い.

電気光学結晶の $+z$ 面にパターン電極を形成し， $-z$ 面を 一様な接地電極として電界を印加すると, + z面から分極 反転が進行してパターン電極形状の分極反転が結晶内に 形成される。これによって電気光学効果の符号が場所的 に異なる結晶を作成することができる，分極反転後に結 晶両面に一様な变調電極を形成して一様電界を印加した とき，結晶を通過する光波の波面は，光波が通過する方 向に反転電極形状のレプリカとなる。このため, 分極反 転を利用することによって, 任意の空間光変調器が作成 できるようになった。

な抢分極反転後の結晶中には, $5 \mathrm{kV} / \mathrm{mm}$ 程度の電界が分 極反転壁周辺を中心に残留する ${ }^{3)}$. これが結晶の電気光学 効果を介して複屈折効果をもたらすため, 透過波面が歪 んでしまい，そのままでは光空間変調素子として使うこ とはできない、熱アニール等によって, この残留電界に よる波面歪みを解消することが必要である. 


\section{1 電気光学偏向器}

最も簡単な光空間変調器は電気光学偏向器である. 電 気光学偏向器は通常の光エレクトロニクスの教科書にも 記載されるなど，古くから知られていた4). しかし従来， それを作成するには高度な結晶研磨技術が必要であり， 実用化は困難であった。しかし，分極反転技術によって 作成が可能となり，いくつかの報告と商品化がされるよ うになった ${ }^{3,5)}$.

分極反転を用いた電気光学偏向器の例をFig. 1 に示す. 電気光学結晶の+ $z$ 面に光通過面に対して傾いた, 三角形 状の電極を形成して分極反転を行う，変調時にはこの結 晶全体に一様な電界を印加するが，このとき反転部の屈 折率が増加したとすると非反転部の屈折率は減少する。 そのため反転部と非反転部との界面で光ビームの屈折が 起こり，光ビームが偏向される，印加電圧に対する偏向 特性の一例をFig. 2に示すが，偏向角は印加電圧に比例し ており，理論とよい一致を示している.

電気光学偏向器の能率は, 遠視野でビームを 1 スポット 分だけ移動させるのに必要な電圧で記述される．光偏向 器の出射面では光波面が印加電界に比例して傾くが, 光 波の進行方向(偏向方向) はこの波面に垂直であり，素子を 通過する光ビームの大きさにはよらない. しかし光ビー ムの広がり角はビーム径に比例するため, 最大光偏向角 とこのビーム広がり角の比が分解可能スポット数とな る. 効率よく光偏向器を動作させるには素子幅全体に光 ビームを通過させる必要がある。このとき1スポット分だ け光ビームが偏向するのは, 素子断面内での最大光路差 が半波長となるときである。これは通常の電気光学変調

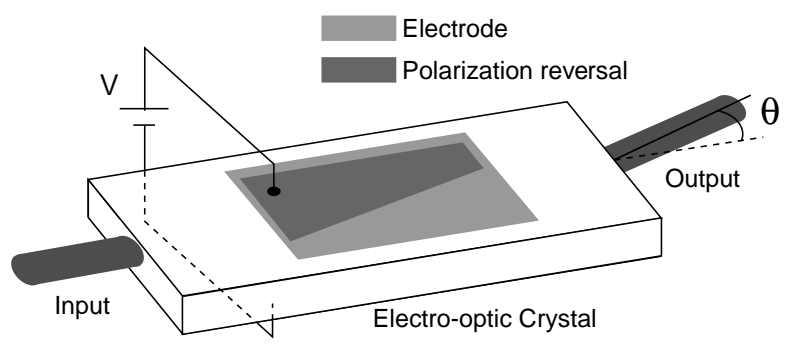

Fig. 1 Electro-optic deflector with polarization reversal.

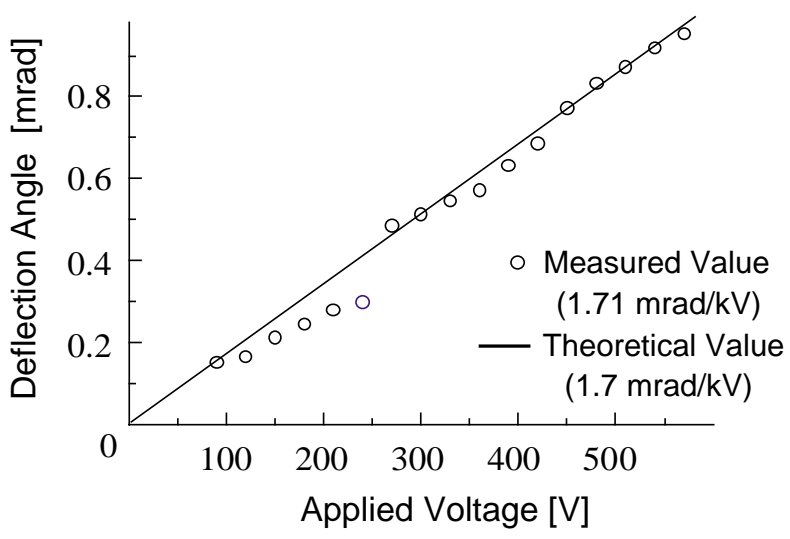

Fig. 2 Deflection characteristics of the electro-optic deflector.
器における半波長電圧と同じであり，バルク素子では一 般に数十ボルトから数百ボルトになる。これらの電気光 学偏向器で分解可能なスポット数は数十から百程度とな る。

動作周波数は電極の静電容量によって制限されるが, 数十 MHz程度以上まで可能であり，光ビームの分配やス イッチとしての応用が期待される6).

\section{2 電気光学波面制御器}

電気光学偏向器は光波面の一次空間制御であったが, これは分極反転形状に依存することから，任意の光波面 制御も可能である. Fig. 3は直線, 放物線, および3次曲線 の波面制御部を一つの電気光学素子に形成したものであ る7). 分極反転部ごとに, 電気光学偏向器, 電気光学レン ズ, 3次歪補正器であり, 波面の級数展開による一次元任 意波面制御器となっている. 各々の素子の動作も理論通 りであることが確認されている。電気光学レンズでは, 口径数ミリメートルの場合, キロボルトあたり数ジオプ トリーのシリンドリカルレンズとなっている.

分極反転が結晶中で一様に進行することからこうした 素子の動作は基本的に一次元であり，真の任意波面制御 である二次元動作には二素子を組み合わせるなどの工夫 が必要である。

\section{3 電気光学位相格子}

周期的な分極反転を用いると位相格子形光変調器が実 現できる ${ }^{8)}$. Fig. 4に示す素子は電気光学結晶に周期的な分 極反転を施したものであるが，電圧印加によって透過 ビームに対して回折格子(位相格子) となる. 先の電気光学 偏向器とは異なって電圧印加によって偏向角を制御する ことはできないが，比較的大きな角度に光ビームのス イッチングを行うことができる。スイッチに必要な電圧

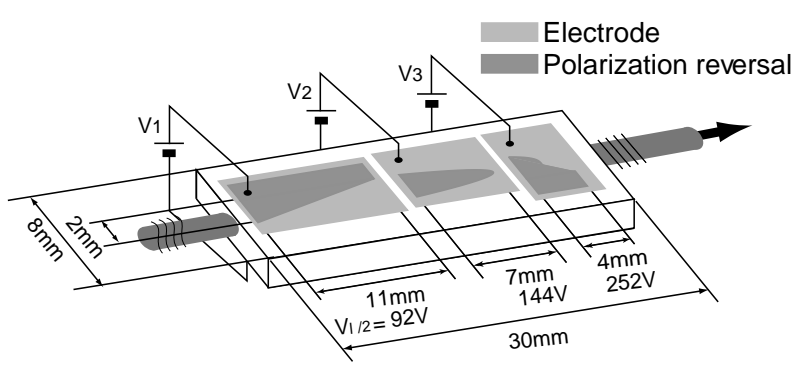

Fig. 3 Electro-optic wave front controller. Three electrodes corespond to a deflector, a lens, and an aberration corrector.

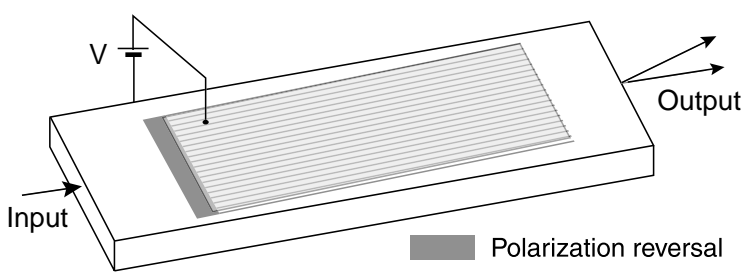

Fig. 4 Electro-optic phase grating with periodic polarization reversal. 
は通常の光変調器における半波長電圧と同じである.

電気光学位相格子ではブラッグ回折によって光ビーム の切り替え機能を実現することができるが，そのために は分極反転を数十マイクロメートルと短い周期のものに しなければならない，分極反転周期がそれよりも長い場 合にはラマン・ナス回折状態になり, 一つの回折ビーム に対して $100 \%$ の回折効率を得ることはできない.ラマ ン・ナス回折の場合には, 0次回折光を用いた強度変調器 としての利用が考えられる。

\section{3. 擬似速度整合形電気光学変調器}

ギガヘルツ領域の高速電気光学変調器を作成する場 合, その帯域を制限する最も大きな要素は, 光波とマイ クロ波の速度非整合である。通常の電気光学結晶中で は, 光波はマイクロ波よりも数倍速く進むため, 変調電 気信号であるマイクロ波を光波が追い越してしまい，同 じ位相のマイクロ波と光波が相互作用を続けることがで きなくなってしまう。これが速度非整合であり，進行波 光変調器構成において相互作用長を制限し, 変調能率が 限られたものとなる原因になっている.これは非線形光 学結晶による波長变換において問題となる位相不整合と 同様である。

いま結晶中の光波の速度 (群速度)を $v_{\mathrm{g}}$, マイクロ波の速 度 (位相速度)を $v_{\mathrm{m}}$, 変調周波数を $f_{\mathrm{m}}$ とするとき,

$$
L=\frac{1}{2 f_{\mathrm{m}}\left(1 / v_{\mathrm{m}}-1 / v_{\mathrm{g}}\right)}
$$

なる距離 $L$ だけ光波が進行すると, マイクロ波を半周期分 だけ追い越すため，これ以上相互作用を続けても逆に変 調は打ち消されて小さくなる. $\mathrm{LiNbO}_{3} や \mathrm{LiTaO}_{3}$ といった 電気光学結晶では, $10 \mathrm{GHz}$ 以上のマイクロ波周波数にな るとこの距離は数ミリメートルになり, 効率の高いマイ クロ波光変調器を設計することを困難にしている.

そこでこのLごとに結晶軸を反転させておけば，Fig. 5 に 示すように変調はいつまでも打ち消されることなく伝搬 にともなって増大することになる，これが擬似速度整合 であり，非線形波長変換素子における擬似位相整合と同 じ原理である. 擬似速度整合では, Fig. 5からもわかるよ うに, 速度整合が完全である場合に対して変調指数は $2 / \pi$ に低下するものの，ほぼ相互作用長に比例している。こ れを用いると, 特定のマイクロ波周波数で極めて大きな 変調能率を有する電気光学変調器を設計することが可能 となる。

Fig. 6は擬似速度整合形マイクロ波光学変調器の外形を 示している. $\mathrm{LiTaO}_{3}$ 結晶に周期分極反転を施し, $17 \mathrm{GHz}$ で動作する共振電極をマイクロストリップ線路によって 形成している。この変調器は極めて大きなマイクロ波位 相変調を光波に印加することができるが，それによる光

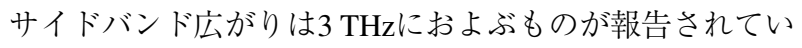
る9).

このような大振幅位相変調はフェムト秒光パルス生成 やフェムト秒光波形整形に応用できる他, 超高速光パル

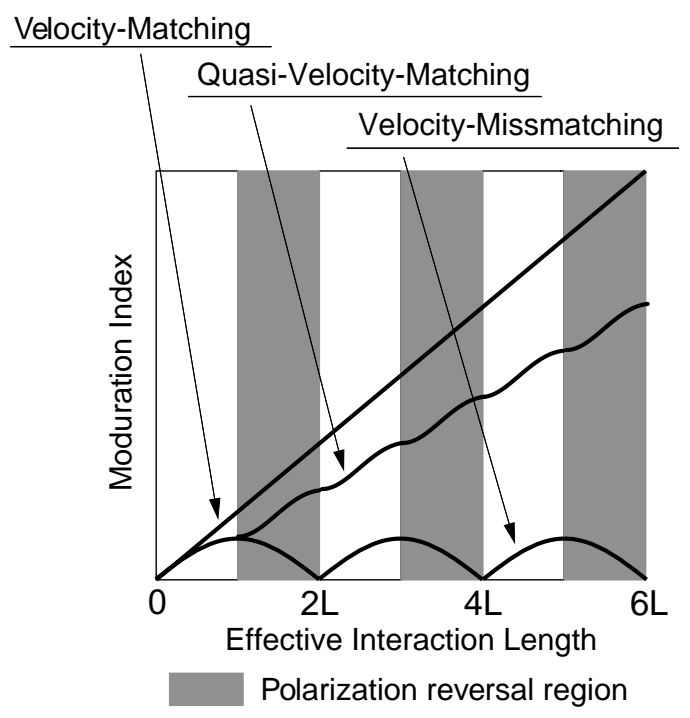

Fig. 5 Microwave modulation indices as a function of interaction length.

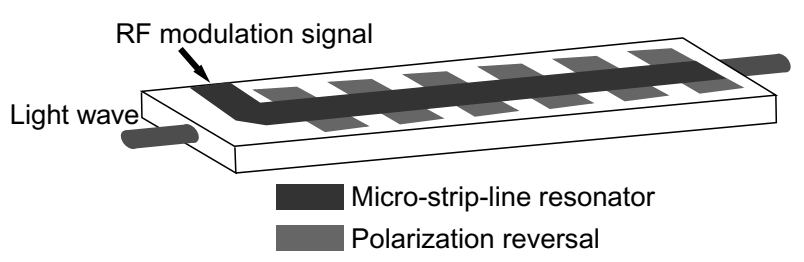

Fig. 6 Quasi-velocity-matched electro-optic phase modulator with periodic polarization reversal.

スのコヒーレンス制御にも有効であり，核融合用レー ザーのビーム形状改善にも利用されている10).

周期分極反転では特定の一つの周波数でのみ变調効率 が高かった．しかし，非周期の分極反転を用いればマイ クロ波変調帯域の制御も可能であり, 広帯域化等が可能 である。これはRadio-on-fiber用の高効率光変調器等として 期待される.

\section{4. 進行波位相格子形光変調器}

周期分極反転による擬似速度整合形光位相変調器の変 調特性においては, Fig. 5に示すように光波の進行にとも なって特定の周波数でのみ変調が積算されるが, 周期分 極反転の空間位相も最終的な位相変調に影響する。この ときマイクロ波光変調の位相は, 周期分極反転の空間位 相に比例して変化するという特徽がある。これはマイク ロ波変調の位相を分極反転によって空間的に制御できる ということを表している. 例えば同じマイクロ波変調信 号と同じ電極を用いても，周期分極反転の空間位相を $1 / 4$ 波長ずらすことによって, $\sin$ 変調と $\cos$ のマイクロ波変 調を行う変調素子を作り分けることができるのである.

この特性を用いた素子にFig. 7に示す進行波位相格子形 光変調器がある ${ }^{11)}$. 斜めの周期分極反転を用いて進行波 形のマイクロ波変調を行うが, 光およびマイクロ波の相 互作用方向には先の擬似速度整合形電気光学変調器と 


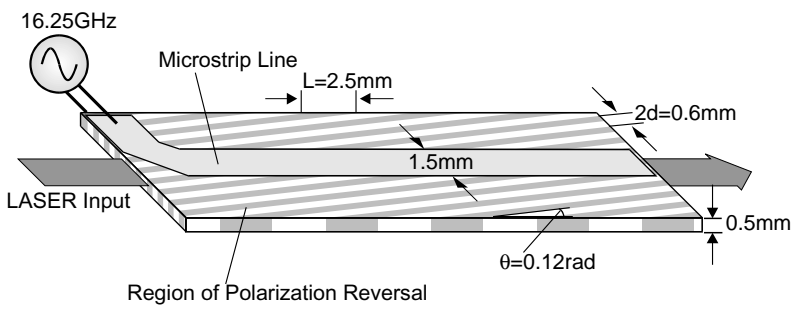

Fig. 7 Travelling phase grating with slant periodic polarization reversal.

なっている．ただし光ビーム断面内で擬似速度整合の空 間位相が直線的に変化していることから，マイクロ波変 調の位相も電極の断面内で直線状に変化したものとな る。このため, 素子出力断面での波面は正弦波状とな り，時間とともに進行する，つまり進行波位相格子にな る ${ }^{12)}$. これは音響光学変調器によるものと同様の動作で あるが, 音響光学変調器では動作周波数は数百 $\mathrm{MHz}$ であ るのに対し, この電気光学素子ではマイクロ波領域で動 作が実現できる。

Fig. 8はこの素子による回折スポットの実験結果を示し ている。これは分極反転周期が比較的大きい場合の結果 であり，マイクロ波変調によってラマン・ナス回折が起 こり, 複数の回折スポットが現れている. 隣接スポット 間では, 光周波数の差はそれぞれ変調周波数である 17 GHzだけ離れている。この素子は光周波数生成と空間分散 の双方を兼ね備えており, 空間内に分散された光周波数 コム生成器となっている。

これらの空間分散された光はラマン・ナス回折の原理 に基づいているため，それぞれの振幅は $n$ 次のベッセル関 数 $J_{n}(\Delta \theta)$ で与えられ，互いにコヒーレントである13)。これ

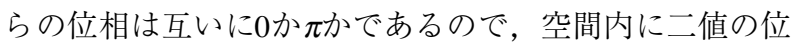
相マスクを配置することによって，全てを同位相に調整 することができる。これは周波数合成による超短光パル ス発生を空間的に行ったものと考えることができ，この とき遠視野での光ビームは一方向に超高速で走査され る2). そのような超高速光走査実験結果および計算例を Fig. 9に示す14). このような光ビームは超高速光制御に有 用であり，超高速光分配やシリアル・パラレル変換に有 用と考えられている。

分極反転周期をさらに微細にすれば，ブラッグ領域に することもできるが，このときは回折スポットは一つだ けとなり, 光周波数シフタとして機能する。このとき, 変調に必要な電圧は通常の光変調器の半波長電圧と同じ になる。この原理による $10 \mathrm{GHz}$ 領域のマイクロ波光周波

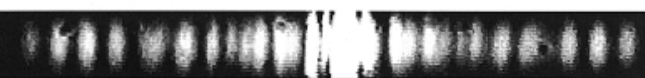
.Illı III I L II ill.. $17 \mathrm{GHz}$, Modulation Index 10.0rad

Fig. 8 Diffraction pattern of the the travelling phase grating.
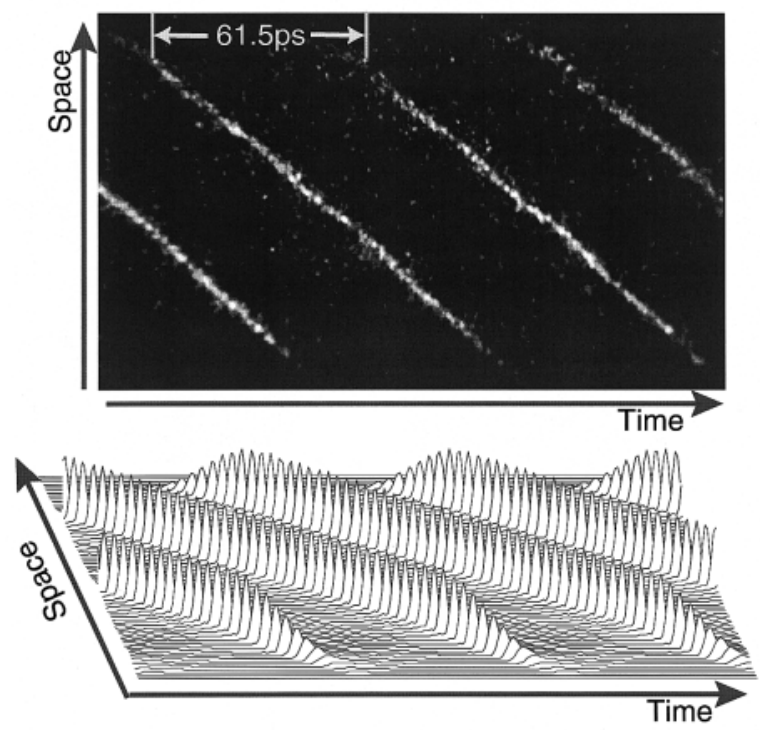

Fig. 9 Ultrafast laser beam scanner with the phase grating and spatial phase control.

数シフタが報告されている15).

\section{5. その他の空間変調素子}

周期分極反転を用いた擬似速度整合形電気光学変調器 では，マイクロ波変調の位相を反転の空間位相で制御で きたが，変調振幅を空間的に制御することもできる. Fig. 5 に示したように擬似速度整合形電気光学变調器の変調能

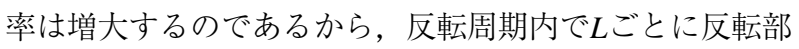
と非反転部のデューティー比を制御すればマイクロ波変 調度を空間的に制御することができる16)。これによって 定在波位相格子形マイクロ波変調器が報告されている が，マイクロ波領域の超高速光ゲートとして動作する。 レーザーのモード同期には定在波形の音響光学変調器を 用いることが多いが，そうした変調器のマイクロ波版と して動作する。

擬似速度整合により変調振幅および変調位相が自在に 制御できることは，マイクロ波領域でも任意波面生成器 が実現できるということを表している。マイクロ波変調 によって，ある波面からもう一つの波面へと周期的に変 化させることができ，この波面形状を分極反転で任意に 設計できる。

\section{6. 分極反転を利用した導波形素子}

分極反転の利用は導波形光変調器においても有用であ る，導波形にすることによって変調電圧の低減を図るこ とができ，光通信分野において有用な素子となるからで ある．周期分極反転による擬似速度整合は導波形光変調 器でも有効であり，チャネル導波路を用いたものも実現 されている17)。導波形では空間光変調器としての利用は 困難であるが，複数の光導波路に異なる変調特性を与え ることにより類似の機能を実現できる．例えば擬似速度 整合の空間位相を利用して，二つの導波路に $\sin$ 変調と $\cos$ 
変調を行い，SSB変調が実現できることも最近報告されて いる18).

以前よりバルク形電気光学变調では, 結晶の方向を反 転させて温度その他の特性安定化を図ることが行われて きた。分極反転によって導波形光変調器においてもこれ らの手法が使えるようになり，温度安定化やチャープ補 償などが報告されている ${ }^{19)}$. 今後様々な応用が期待され る.

\section{7. むすび}

分極反転を用いた電気光学デバイスについて報告し た. 分極反転により電気光学結晶の一部分だけの変調符 号を反転させることができるようになり，従来は複数の 結晶を組み合わせて実現していた光変調器の機能が一つ の結晶だけを用いて容易に実現できるようになった。ま た理論的にはわかっていても，研磨技術のために実現で きなかった空間変調器としての機能も現実のものとなっ た。これらはバルク形光変調器だけでなく, 導波形光変 調器にとってもきわめて有用であると考えられる。

周期分極反転を利用したマイクロ波光変調素子では, その変調度および変調の位相を自在に制御することがで きるため，様々な機能を実現できることを示した．空間 変調器および集積化導波形光変調器として, 新しい機能 が期待できる。

分極反転を実現するには放電破壊電圧に近い比較的大 きな電界が必要であった，定比組成結晶ではこの分極反 転電界が一致溶融組成の場合の 10 分の1以下であり，素子 の作成が容易となることが知られている。しかしなが ら，電気光学素子では変調に比較的大きな電界を必要と するため, 分極反転電界が印加可能最大電界となると機 能が限られたものとなる恐れがある。定比組成結晶のマ イクロ波変調器への応用や, 定比組成と一致溶融組成の 中間状態にある結晶の利用が今後の課題である.

こうした分野は最近研究が進められるようになったも のであり，今後の発展が期待される.

\section{謝 辞}

日頃からご教示, ご指導をいただく, 大阪大学大学院 基礎工学研究科 小林 哲郎教授に感謝する。

\section{参考文献}

1) T. Yajima, H. Yajima, F. Saito, and O. Wada, Eds.: "Femtosecond Technology" (Springer-Verlag, 1999).

2) 森本 朗裕：光学 30 (2001) 510 .

3) 森本 朗裕, 井邨 泰之, 小林哲郎: 第40 回応用物理学関係連 合講演会, 30a-SA-23 (1993).

4) A. Yariv: “光エレクトロニクス, 展開編” 多田, 神谷訳 (丸 善, 2000).

5) D. A. Scrymgeour, Y. Barad, V. Gopalan, K. T. Gahagan, Q. Jia, T. E. Mitchell, and J. M. Robinson: Appl. Opt. 40 (2001) 6238.

6) 安達雅浩, 黒川悟, 蒲原 崇之, 和田泰輔, 森本朗裕：第 63 回応用物理学会講演会, 26p-B-12 (2002).

7) 和田泰輔, 日比野卓也, 國松俊介, 森本 朗裕: 第60回応用 物理学会講演会, 4a-K-1 (1999).

8) H. Gnewuch, C. N. Pannell, G. W. Ross, P. G. R. Smith, and H. Geiger: IEEE Photonics Technol. Lett. 10 (1998) 1730.

9) D. -S. Kim, T. Khayim, A. Morimoto, and T. Kobayashi: IEICE Trans. Electron. E81-C (1998) 260.

10) G. Miyaji, N. Miyanaga, S. Urushihara, K. Suzuki, S. Matsuoka, M. Nakatsuka, A. Morimoto, and T. Kobayashi: Opt. Lett. 27 (2002) 725 .

11) A. Maruko, T. Khayim, T. Kobayashi, and A. Morimoto: CRL Int'l Symp. on Optical Commun. and Sensing toward the Next Century, Tokyo, C-7 (1999) p.211.

12) A. Morimoto, T. Khayim, A. Maruko, and T. Kobayashi: CLEO/ Pacific Rim '97, Makuhari (1997) p.38.

13）小山 次郎, 西原 浩: “光波電子工学” (コロナ社, 1988).

14) T. Khayim, A. Maruko, K. Shibuya, A. Morimoto, and T. Kobayashi: IEEE J. Quantum Electron. 37 (2001) 964.

15) 渋谷享司, 小林哲郎：第64回応用物理学会学術連合講演会, 30p-YK-13 (2003).

16) 神谷 健太郎, 渋谷亨司, 小林哲郎, 森本 朗裕: 第62回応用 物理学会講演会, 11p-Y-11 (2001).

17) H. Murata, K. Kinoshita, G. Miyaji, A. Morimoto, and T. Kobayashi: Electron. Lett. 36 (2000) 1459.

18）村田 博司, 廣澤 慶二, 金田一賢, 岡村 康行, 笹井 裕之, 榎原 晃：第64回応用物理会学術連合講演会, $30 \mathrm{p}-\mathrm{YK}-9$ (2003).

19）及川哲，山本太，本田 秀紀，市川 潤一郎，野村 善行，栗 村 直：第64回応用物理学会学術連合講演会, 30p-YK-6 (2003).

\section{分極反転 (polarization reversal)}

強い外部電界等によって, 強誘電結晶の自発分極の方 向が反転すること. 結晶中のイオンの位置が電気的に対 称な位置から少しずれている場合に起こる。結晶軸の向 き自体が反転するため，これにともなって非線形光学定 数や電気光学定数の符号も反転する. 強誘電材料ではよ く知られている現象であり，メモリ等に応用されてい
る. 非線形光学結晶や電気光学結晶も強誘電結晶である が，分極反転に必要な電界は通常極めて大きい。結晶の 破壊電界に近いために従来は反転不能と考えられていた が，近年作成が可能となって光学的な応用分野が広がっ ている。

(森本 朗裕) 